\title{
Production Control through Costs Based on Activities - Case of the Romanian Companies
}

\author{
Violeta Maria ISAI $^{\star}$, Caterina NICOARA OANA ${ }^{\star \star}$, Riana Iren RADU ${ }^{\star \star \star}$
}

\author{
A R T I C L E I N F O \\ Article history: \\ Accepted June 2019 \\ Available online August 2019 \\ JEL Classification \\ Keywords: \\ Costs, Activities, Cost centers, Cost \\ inductors, Cost matrix
}

\begin{abstract}
A B S T R A C T
It is known that the cost of production holds the largest share of the total operating costs of a company. Therefore, in order for a company to survive, grow and pay its shareholder by generating a reasonable profit, the effective and efficient control of such a cost by management becomes very important. When the cost is not properly controlled and maintained by ensuring that actual results are in line with predefined standards, it could result in higher operating costs, lower profit margins, and ultimately discontent among owners and potential investors.
\end{abstract}

(c) 2019 EAI. All rights reserved.

\section{Introduction}

The main objective of this paper is to critically review the cost control methods used by a production organization and also to propose an alternative action if necessary. Monitoring production costs becomes essential in establishing the sales prices of the manufactured products. Even the smallest change in the manufacturing process can generate increases or decreases in the annual output of the business. Therefore, management can use this opportunity to maximize the profit without having to raise prices much. Before starting the cost calculation, all necessary information about the actual cost of manufacturing a product over a fixed period of time will have to be gathered. These include direct costs, such as materials and workforce, as well as indirect costs, such as equipment wear. For the entities producing and selling a single product, the cost calculation is easy, compared to the entities producing multiple items / products. Managers use cost accounting information to make decisions about strategy formulation, research and development, budgeting, production planning, and sales pricing. It is natural that no production company can afford to invest its insufficient resources if not has the ability to control, and then it is obvious that the importance of studying the methods of controlling production costs cannot be neglected.

\section{Method of costs based on activities - efficient production control instrument}

The ABC method was designed in the mid-1980s by Robin Cooper (professor of management in designing and practicing computer systems) and Robert Kaplan (professor of management accounting at Harvard University). It was mainly developed to correct misalignments. It is a refined cost system that favors a better allocation of costs, using lower cost groups, called activities. By using cost drivers, the costs of these activities are the basis for allocating costs to products or services. The method represents an approach to the cost of final production by monitoring activities and tracking the resource use by activities. The resources are allocated to activities and the activities to the cost elements based on consumption estimates. The latter uses the cost mechanisms to attach the costs of the activity to the outputs. By this technique, the cost / management of core activities is considered to eliminate activities that do not add value to customers and organizations and minimize or avoid distortion of product costs that may arise from arbitrary allocation of general costs. The ABC method identifies resource-consuming activities by adjusting the cost of these activities. The key aspect of this methodology is the development of models that represent a logical and quantifiable relationship between the use of resources, the performance of the activities and the products or services they offer. These models can simultaneously reflect the flow of orders and products along the logistics chain and cost capture at a disaggregation level that allows for the profit analysis by customer type, market segment, and distribution channel. 
For a better understanding, the advantages and disadvantages of the ABC method are presented below:

Advantages: An ABC costing system generates more accurate product information, especially in cases of high product diversity. The $\mathrm{ABC}$ focuses on the analysis of several cost objects, assuming it plays the role of a decision-making instrument at the strategic level. It allows a closer analysis of cost behavior, identifying the various factors to which they are sensitive, and providing information that can be used in production control and management.

Disadvantages: high implementation costs, constant need for review, complexity of data, difficult data extraction, need to reorganize the company before implementation, difficulties in integrating information between departments, lack of a competent, qualified and experienced staff for implementation and tracking.

The ABC method can be considered as an alternative method to the traditional cost calculation methods, being designed to correct the shortcomings of the traditional costing systems. The ABC system focuses on indirect production costs. The goal is to define the most appropriate way of indirectly allocating production costs to cost objects. The main assumption of the ABC system is that products consume activities and activities consume resources. The more activities are created, the more complex the ABC system is. An activity is defined as any event, action, transaction, or work sequence that generates costs when producing a product or providing a service. Basically, the application of the ABC system goes through two main phases. In the first phase, the indirect costs of production are allocated to the cost groups of activity. It is important to determine the correlation between the indirect cost of production and the identified activity. All indirect production costs must be attributed to the corresponding activity that causes them to occur. The second phase of the $\mathrm{ABC}$ application is to assign indirect production costs from cost bases to products using defined costs. A cost factor is any factor or activity that has a direct cause-to-effect relationship with the resources consumed.

The ABC system uses multiple cost allocation bases to allocate indirect production costs for products or services. Using multiple allocation bases can provide a more accurate and objective product cost assessment. The ABC method allows you to analyze the impact of activities on real profitability for a specific purpose, to identify cost very precisely, the effects of new products' activities and their allocation to customers, the cost of production being the starting point for setting the sales prices. However, many entities calculate a sales price determined on the basis of the accumulation of costs, derived from salary increases, the cost of materials, or a coefficient or multiplier applied to them and determined by type of benefit, product or customer.

In the private sector, thousands of companies with a wide range of activities have adopted cost-based and management-based approaches to manage costs and increase the revenue. A vital advantage of this method is how it makes the specialists think of a more efficient management, taking into account the possibilities of determining real costs, especially in the current business environment, while the competition is becoming more fierce. Measuring the performance by defining key performance indicators (which are extracted from the budget for specific cost control areas) is one of the possibilities. This allows the manager to periodically check the performance of the business to ensure that it works in accordance with the budget. In the affirmative, the desired profit goal will be achieved. Controlling production activity through costs must be a priority for the manufacturing companies, and the main source for calculating production costs is the data on the production process and the size of expenditure.

\section{Implementation of the ABC method in Romanian steel companies}

When choosing a cost management system, a set of criteria is set to meet the company's mission, always respecting the cost / benefit ratio. Taking into account the technological advances and the growing complexity of the production systems and the frequent change of the vision of the decision factors within the company, it was decided to adopt the ABC method as a costing technique. The ABC implementation required a careful analysis of the internal control system of the companies, as an example, definition of functions and flow of processes, classification of expenses in variables and fixed ones. Thus, expenditures on raw materials, auxiliary materials, other direct materials, direct salaries, direct energy fluids and technology depreciation, packaging costs were considered variables. All these costs are collected at the main cost centers and / or on the CO production orders, respectively internal orders. The fixed expenses are: with indirect wages, depreciation, current and capital repairs, other equipment maintenance costs, technological materials, labor protection, environmental and administration protection at the department level. These costs are exclusively collected on cost centers per destination. Although they have fixed-cost behaviors, the following expenditure categories have a separate arrangement: financial expenses, general administration expenses and expenditure on external sales costs - are collected at the cost of general administration costs and are not allocated to the cost of production of the products, eventually transferring into the profitability mode to determine the profitability of the products over the full cost. 
The implementation procedure covered seven major stages:

Stage 1: Setting the objectives and requirements of the costing system - at the beginning of the ABC implementation, the company's management decided the main purpose of using the costing system. For example, the common objectives of a costing system are to control costs and measure profitability. Regardless of the main objectives, the ABC's main purpose is to target general costs (rents, utilities, administrative salaries, office expenses). Depending on the objectives, the management also chose the accuracy of the costing system. During the phase and based on the objective of using the costing system, the management has decided what cost items will be used in the analysis. The objective and requirements of the ABC system are in line with the company's overall business strategy.

Stage 2: Identifying general activities - all of these activities are directly related to product distribution or customer service. In addition, there are a number of activities developed in the company that are defined as support activities, such as human resources.

Stage 3: Tracking the activity by using the Resource-Activities matrix. After identifying major activities, the general expenses are tracked from costs to activities. During this stage, general expenses are obtained from accounting records and then related to activities using the matrix. Essentially, the matrix has helped determine the consumption of each activity.

Stage 4: Tracking the general expenses on cost objects using the Product-Activity matrix - once the costs for all activities have been determined, the matrix has been used to link the activities and the cost centers and, also, to track general expenses on cost centers.

Stage 5: Tracking the direct costs on cost centers - in addition to general costs, there are costs that can be directly attributed to the cost centers. Thus, during this stage, all direct costs are identified and assigned to cost centers.

Stage 6: Calculating the cost per product for each cost item - the cost of the product (or an estimate of the total costs that occur when a cost item is generated) is calculated by adding together the direct costs and general expenses.

Stage 7: Using the ABC analysis for Business and Strategic Decision Making - After performing the $A B C$ analysis (Stages 2-6), the information obtained was used by managers to take action to improve operational and strategic performance.

\section{Application of the $\mathrm{ABC}$ method in different fields of activity-comparative analysis}

Based on the real cost calculation, which has become an important aspect of the organizations with production and service activity, the $\mathrm{ABC}$ can be defined as a methodology that measures the cost and performance of activities, resources, and cost items. Due to its versatility, the method can be implemented in various types of companies - from mining companies to on-line commerce.

\section{Extractive industry}

The general principle of the $\mathrm{ABC}$ method for the allocation of costs on activity and on product in the mining and quarrying industry can be simplified as follows: expenditures for cost centers - allocation of costs on activities - activity centers of cost - allocation of costs based on cost inducers on the product - the cost per ton of produced coal. The $\mathrm{ABC}$ method involves the delimitation of processes and activities in: main (production processes) and secondary (administrative processes). The production process includes the main processes (identified by production centers) and secondary (identified by surface activities and underground activities). The main activities include: extraction process, coal preparation, sterile preparation, mine maintenance, transport, frontal extraction, complex assembling and dismantling, and the secondary activities identified are: service of flow systems, dosing maintenance, water evacuation, repairs, fan maintenance, maintenance of mining, explosive storage, pyrotechnics and drilling works. The main activities can be allocated without difficulty to the level of production cost (cost object), instead, secondary activities can be considered, as the case may be, direct activities, because it is impossible to identify the customers who will consume or can be allocated directly to the cost objects. Allocations represent the links between causality and cost objects and are found in the settlement rules contained in the implementation procedure, and for simplification, the activities have been grouped into activity families. For each activity, a certain amount of information is collected to get all $\mathrm{ABC}$ application needs.

According to the $\mathrm{ABC}$ method, the cost centers are the units of measure used to allocate the indirect costs and monitor the indirect costs related to activities (production, management, marketing, etc.) on cost items (deliveries, works, services, etc.). Cost allocation processes are used to calculate the cost of cost resources that are consumed. Improving the information system by ABC, allows the manager to react quickly to choose for reviewing sales prices before launching the production at a production center. The analysis of expenditure on activities carried out in a production center allows a more precise determination and allocation to be defined, obtaining the same efficiency in each cost center, and the cost of production reflects a real cost, with a fair distribution of the costs of the activities on each ton of coal produced.

The approach proposed by the $\mathrm{ABC}$ method represents the means of reconfiguring of the sales price and a solution for improving the cost-effectiveness of costing. The $\mathrm{ABC}$ method allows for new operations 
either at the cost of "selling" the production costs or selling services for which the sales price is displayed and transparent and / or the cost of collapse of the cost, the service not being borne by the customer but by the provider. This new method for determining the sales price was conceived by considering two directions: identifying customer benefits and calculating the low cost of production based on the activities.

One of the most important contributions of the $\mathrm{ABC}$ method in the extractive mining industry in Romania is that it remedies the weaknesses of traditional approaches for calculating production costs and thus is the guarantor of obtaining real costs. At present, in most Romanian entities, including in the mining sector, there is an increase in non-productive activities (non-market), and the ABC method allows most indirect costs to be allocated for the manufactured products, performed works or provided services. The ABC method focuses on actual cost behavior, helping to identify the activities which do not bring value and using multi-cost factors that highlight the direct cause-and-effect relationship between the allocation expenditures and the used allocation bases.

\section{Aerospace industry}

Companies that produce aircraft spare parts, which would like to increase sales due to demand rising, need to know the real cost of the parts before deciding on what product to increase production, which product brings losses and what activity brings value. The implementation of the $\mathrm{ABC}$ method in a company that has as main activity the production of spare parts (aerospace products) involves the following steps: identification of activities, identification of cost inductors for each activity, allocation of product costs, determination of product costs and profit.

The activities identified within the company are: research, supply, production and non-productive activities (sales, human resources, marketing, accounting, financial). The cost drivers set for each activity are: the number of research hours, the number of suppliers, the number of orders, the quantity of raw materials, the number of batches, the direct workmanship, the number of manufactured products and the added cost. The allocation of product cost activity on products was determined, based on the cost of the cost inductors set as the ratio between the cost per activity and the volume of the corresponding cost inductor, based on the technological process of execution for each product. In the last stage, the indicators for determining the costs of products, the unitary and total profit are established. From the analysis of the costing information, the company's management can decide what profit-generating and loss-making products are, as well as the added-value activities. Adoption and implementation of the ABC method has led to real cost estimation, which is an advantage, especially in today's business environment where competition is growing.

\section{Service provision in Agriculture}

The application of the $A B C$ method was decided also by the need for a more realistic distribution of indirect costs and return of the profitability centers on the basis of which the share of the company's general expenses was established. The following steps have been followed in implementing the ABC method: identification of activities (equipment repairs, exchange of spare parts, staff training, equipment service for economic entities, leasing); classification of activities; evaluation of the resources consumed by each activity; re-grouping activities by the same resource inductor into: production, commercial and service activities.

The main advantages of implementing the method, in addition to the accuracy of costing and analysis, are also those related to measuring company performance and, as costs are determined by activities and cost items, there are also many analytical possibilities for establishing ways to reduce costs, changing marketing strategies, setting responsibilities for decision-makers, and adopting the results-oriented management.

\section{Clothing industry}

The implementation of the $\mathrm{ABC}$ method as a cost calculating method was decided because indirect costs have a large share in the total cost of production and is aimed at highlighting activities that do not bring additional benefits to the finished products, realistic distribution of indirect costs, and analysis that is more detailed on cost-generating elements.

The implementation procedure provides for the following steps: Identification of the activities and their specific costs (launch in the manufacture - includes the costs of services rendered by the third companies for the issuance of the patterns, expenditures with the inventory objects, processing - includes indirect labor and related contributions, equipment costs and electricity expenses); Determination of cost factors (number of products launched in production for the production launch activity, direct labor for the processing activity, hours of operation of equipment for the operation of the equipment); Distribution of indirect costs of the activities by product type.

Due to the distribution of costs by activity and then by product, depending on the cost factors, distribution is more relevant and allows more effective analysis of those elements that have generated costs in the company's business. All the information generated by the ABC method allows the manager to react quickly to reviewing sales prices before launching the products in order to be competitive on the market. 


\section{On-line trade}

Given the fact that the cost management system on which the ABC method is based proved effective in keeping costs in traditional companies under control, more and more online businesses companies have decided to implement it as a costing method. E-commerce poses a substantial risk, and many Internet companies face higher global costs than traditional comparable companies do. It is one of the reasons that led to the decision to implement the $\mathrm{ABC}$ method in order to lead to a better performance in offering products and services by Internet and to help managers in e-commerce companies understand the value of a reliable calculation system.

The implementation methodology is adapted to the specific needs of the electronic commerce, it uses matrices to determine general expenses and involves seven steps, as follows: Establishing objectives and requirements; Identifying activities; Determination of cost inducers; Establishing activity-based costing; Identifying and attributing direct costs; Calculation of product cost; Analyzing the results.

The main objectives aimed by the managers based on the information provided by the ABC analysis are: verifying the profitability of the loyal customers and identifying profitable and unprofitable products. In addition, the $\mathrm{ABC}$ method offers potential in leading on-line business to effective levels, helping to establish efficient operations and strategies. The $\mathrm{ABC}$ analysis allows managers to measure reliably the costs associated with e-commerce, helping them to weigh the costs and benefits and prioritize risks. The method also gives them a better understanding of how these costs are generated. The ABC implementation is for the benefit of the companies involved in e-commerce, allowing for better operational performance and improved business strategies, and will thus lead them to the main goals of an organization - profitability.

Taking into consideration the variety of activities in which it was implemented, we can say that the $\mathrm{ABC}$ method is a profit analysis tool. The success of this approach comes from the ABC's ability to highlight the hidden sources of profitability and embedded costs, being a catalyst for profitability improvement decisions within any company.

\section{Conclusions}

The success of an organization depends largely on the profit it can make. The profit is determined by the costs incurred and the extent to which these costs are recovered. It is therefore essential for the organization to know all costs so they can control them. Cost control is the effort that managers make to achieve cost goals in an activity. Good managers need not only understand the conceptual fundamentals of cost behavior but must be able to apply these concepts in real world conditions. In the production process, the costs are affected by complex interactions, and their control is largely based on accounting techniques. The objective of an organization's management must be to develop a cost calculation system that provides cost information throughout the entire production process and allows an effective cost-control.

\section{References}

1.Batca-Dumitru C.G.,Calu D.A.,Ponorica A.G.-Contabilitate manageriala, Ed.CECCAR, Bucuresti 2018

2.Borlea S.,Achim M.,Breban L.-Contabilitate de gestiune, Ed.Risoprint, Cluj-Napoca 2009

3.Bouquin H.-Contabilitate de gestiune, Ed.TipoMoldova, Iasi 2010

4.Briciu S.-Contabilitatea manageriala, Ed.Economica, Bucuresti 2006

5.Budugan D.,Berheci I.,Georgescu I.,Betianu L.-Contabilitate de gestiune,Ed.CECCAR, Bucuresti 2007

6.Caraiani C.,Dumitrana M-Contabilitate de gestiune.Control de gestiune, Ed.Universitara, Bucuresti 2008

7.Calin O.,Man M.,Nedelcu M.-Contabilitate manageriala, Ed.Didactica si pedagogica, Bucuresti 2008

8.Capusneanu S.-Contabilitatea de gestiune-instrument de evaluare a performantei, Ed.Universitara, Bucuresti 2013

9.Diaconu P.-Contabilitate manageriala si Planuri de afaceri, Ed.Economica, Bucuresti 2006

10.Grosu C.,Almasan A.-Contabilitate de gestiune, Editura de Vest, Timisoara 2008

11.Horngren C.T.,Datar S.M.,Foster G.-Cost Accounting-A Managerial Emphasis,Prentice Hall,New Jersey 2003

12.Lepadatu Ghe.-Contabilitatea de gestiune si calculatia costurilor,Ed.ProUniversitaria, Bucuresti 2010

13.Radu M.-Contabilitate de gestiune,Ed.Bibliotheca, Targoviste 2010

14.Sgardea F.M.si colectivul-Contabilitate manageriala aprofundata, Ed.ASE, Bucuresti 2011

15.Tegledi A.M.-Contabilitate de gestiune, Ed.ProUniversitaria, Bucuresti 2015

16.Weygandt, J.J., Kieso, D.E., Kimmel, P.D. - Managerial Accounting, John Wiley \& Sons, US 2005 